ROCZNIKI TEOLOGICZNE

Tom LXVI, zeszyt 4 - 2019

DOI: http://dx.doi.org/10.18290/rt.2019.66.4-5

\title{
KRONIKA KOŚCIOŁA PARAFIALNEGO \\ PW. ŚW. APOSTOŁÓW PIOTRA I PAWŁA W ZABŁUDOWIE JAKO ŹRÓDŁO DO BADAŃ NAD DZIEJAMI MIASTA
}

\author{
CHRONICLE OF THE SAINTS APOSTLES \\ PETER AND PAUL PARISH CHURCH IN ZABŁUDÓW \\ AS A SOURCE IN STUDIES ON THE HISTORY OF THE CITY
}

\begin{abstract}
A b stract. The purpose of the article is to present the problem area regarding the events that took place in the city of Zabłudów between 1927 and 1938. In particular, the analysis focused on the Chronicle of the Peter and Paul Parish Church in Zabłudów written by the then parsons Witold Kuźmicki and Jerzy Sienkiewicz. In the chronicle the authors focused not only on purely religious matters but also on a description of the events concerning many patriotic celebrations in the period being discussed by inhabitants of the city and the surrounding towns. The article also includes an attempt to restore the value of the document in the form of a chronicle as an important source of historical information. The article is intended not only for historians but also for all the persons interested in the regional history from the interwar period.
\end{abstract}

Key words: chronicle; Zabludow; Parish of Zabludow; interwar period.

W twórczości dziejopisarskiej kroniki od dawna stanowiły źródło wiadomości o dziejach państwa i związanego z nim społeczeństwa, zaś wiele pokoleń historyków czerpało z nich wiedzę w pisaniu niejednej pracy naukowej. Termin „kronika” pochodzi z języka greckiego chronikos (dotyczący czasu) i oznacza chronologiczny zapis ważniejszych wydarzeń z życia jakiejś organizacji,

Ks. mgr Andrzej GóRSKI - doktorant w Instytucie Historii Kościoła i Patrologii Katolickiego Uniwersytetu Lubelskiego Jana Pawła II; adres do korespondencji - e-mail: gorski80@wp.pl 
instytucji, państwa lub grupy społecznej ${ }^{1}$. Jest ściśle powiązany ze średniowiecznym piśmiennictwem europejskim i odnosi się do „dzieł opisujących dzieje poszczególnych narodów lub świata"2. W kolejnych wiekach cenną rolę odgrywały prace, które obejmowały swoim zasięgiem mały obszar w wąskich ramach czasowych. Dzięki temu piszący kronikę mógł szczegółowo opisać wydarzenia, jakie miały miejsce na określonym terenie. Doskonałym przykładem takiego dokumentu jest Kronika kościoła parafialnego pw. Św. Apostołów Piotra i Pawła $w$ Zabtudowie, zapisana $\mathrm{w}$ dużej mierze przez ówczesnego ks. proboszcza Witolda Kuźmickiego jak również jego następcę - ks. Jerzego Sienkiewicza.

Zabłudów założono w XV w. Pierwotnie należał do Chodkiewiczów, co potwierdził król Zygmunt I Stary dokumentem z 1525 roku. W 1553 miejscowość otrzymała prawa miejskie magdeburskie. W 1654 roku król Jan Kazimierz potwierdził lokację miasta. W XVII w. w czasie najazdu szwedzkiego (1655-1657) oraz wojny z Moskwą (1658-1660) ulegał kilkukrotnym zniszczeniom. W 2 połowie XVII w. nastąpiło jego ponowne zasiedlenie. Po III rozbiorze Polski (1795) znajdował się pod zaborem pruskim, następnie po 1807 roku pod zaborem rosyjskim. W 1856 roku Zabłudów stał się własnością A. Kruzenszterna ${ }^{3}$. W 1915 roku istniejący dwór spaliły wojska rosyjskie ${ }^{4}$. Parafia rzymskokatolicka została uposażona w 1553 roku przez Grzegorza Chodkiewicza. Drewniany kościół parafialny pod wezwaniem Wniebowzięcia NMP został zniszczony podczas pożaru w 1685 roku. Świątynię odbudowano w 1688 roku i nadano nowe wezwanie Apostołów Piotra i Pawła. W 1762 roku został odrestaurowany dzięki wsparciu M.K. Radziwiłła. W 1800 roku decyzją władz pruskich został rozebrany, a nabożeństwa przeniesiono do świątyni kalwińskiej. Obecny kościół został wzniesiony w latach 1805-1840, konsekrowany w 1856 roku przez biskupa wileńskiego W. Żylińskiego ${ }^{5}$.

\footnotetext{
${ }^{1}$ R.R. KuFEL, Jak prowadzić kronikę parafialna, Agencja Wydawnicza „PDN”, Zielona Góra 2014, s. 26.

${ }^{2}$ Kronika, w: Stownik literatury staropolskiej, red. T. Michałowska, Zakład Narodowy im. Ossolińskich, Wrocław 1998, s. 399.

${ }^{3}$ J. MARosZeK, Prawa i przywileje miasta i dóbr ziemskich Zabtudów, Dział Wydawnictw Filii UW, Białystok 1994, s. 6-7.

${ }^{4}$ Archiwum i Muzeum Archidiecezjalne w Białymstoku (AAB), Inwentarz Zabłudowskiego Rzymsko-katolickiego kościoła z 1927 roku, s. 1.

${ }^{5}$ A. Szot, Zabłudów, w: Encyklopedia Katolicka, t. 20, red. E. Gigilewicz i in., TN KUL, Lublin 2014, kol. 1139-1140.
} 


\section{AUTORZY KRONIKI}

Ks. Witold Kuźmicki pisanie kroniki rozpoczął 30 kwietnia 1927 roku, czyli od pierwszych wydarzeń związanych z jego przyjazdem do parafii zabłudowskiej. Zapewne pod wpływem słów skierowanych przez ówczesnego arcybiskupa Romualda Jałbrzykowskiego ${ }^{6}$, który zachęcał do prowadzenia kronik parafialnych podczas odwiedzania w 1926 roku poszczególnych dekanatów w Archidiecezji Wileńskiej ${ }^{7}$. Ostatni wpis, dokonany przez ks. Kuźmickiego, pochodzi z 9 stycznia 1936 roku, na niespełna dwa miesiące przed jego odejściem z parafii. Adnotacje zapisane na trzech ostatnich stronach, od 26 lutego 1936 do 17 września 1938 roku, pochodzą od trzech różnych osób, w czasie gdy proboszczem parafii zabłudowskiej był ks. Jerzy Sienkiewicz.

Ks. Witold Kuźmicki urodził się 11 maja 1885 roku w zaścianku Orliszki w parafii Sużany k. Wilna, gdzie jego rodzice Adam i Weronika z d. Muczyń byli dzierżawcami majątku. Po śmierci matki, ojciec ożenił się powtórnie i wyjechał z rodziną do Suwałk. W Suwałkach Witold ukończył szkołę powszechną i gimnazjum, zaś w 1901 roku wstąpił do Seminarium Duchownego w Sejnach. W trakcie nauki wyjechał na studia filozoficzne do Rzymu, które uwieńczył doktoratem. Po powrocie do kraju, 28 czerwca 1908 roku w Warszawie przyjął święcenia kapłańskie. Pracował w diecezji sejneńskiej jako prefekt żeńskiej szkoły handlowej w Łomży oraz w kościele katedralnym, lecz po kilku latach poprosił o zwolnienie z diecezji. Do diecezji wileńskiej przyjął go jej administrator ks. prałat Kazimierz Michalkiewicz ${ }^{8}$ i skierował do parafii w Brześciu nad Bugiem w charakterze wikariusza i prefekta. Następnie w 1915 roku otrzymał nominację na probostwo w Dziembrowie w powiecie lidzkim. Tutaj przeszedł wiele ciężkich doświadczeń. Był skazany przez Niemców na śmierć, przeżył kilka napadów bandyckich i inwazję bolszewicką. W 1920 roku objął nowo utworzoną parafię w Dojlidach k. Białegostoku, w której rozpoczął przygotowania do budowy kościoła. Zlecono mu również kierowanie stowarzyszeniami chrześcijańskimi. 2 kwietnia 1927 roku objął stanowisko proboszcza w sąsiedniej parafii w Zabłudowie, gdzie odnowił kościół parafialny, kaplice na starych cmentarzach

\footnotetext{
${ }^{6}$ Ks. Romuald Jałbrzykowski (1876-1955), arcybiskup metropolita wileński w latach 19261955. Por. S. НоŁоDоK, Jałbrzykowski Romuald abp, w: Encyklopedia Katolicka, t. 7, red. zb., TN KUL, Lublin 1997, kol. 737-738.

${ }^{7}$ X. A.N., Kronika parafialna, „Wiadomości Archidiecezjalne Wileńskie” 1927, nr 15, s. 204.

${ }^{8}$ Ks Kazimierz Michalkiewicz (1865-1940), od 1908 roku administrator apostolski diecezji wileńskiej, w latach 1923-1940 biskup pomocniczy w Wilnie. Por. M. CZAJKA, M. KAMLER, W. SIENKIEWICZ, Leksykon Historii Polski, Wydawnictwo Wiedza Powszechna, Warszawa 1995, s. 467.
} 
św. Rocha i św. Marii Magdaleny, ogrodził i poszerzył nowy cmentarz grzebalny św. Krzyża. Założył Akcję Katolicką i odnowił Bractwo III Zakonu. W parafii, liczącej prawie 7000 wiernych, pracy miał bardzo dużo, nie miał wikariusza, lecz pomagał mu kapłan emeryt z archidiecezji mohylewskiej ks. Aleksander Giedrojć ${ }^{9}$. Wyjątkowym polem działania było jego zaangażowanie $\mathrm{w}$ pracę $\mathrm{z}$ młodzieżą, a także działalność patriotyczna i społeczna. W lutym 1936 roku otrzymał nominację na proboszcza i dziekana w Dąbrowie Białostockiej, gdzie pracował do czerwca 1943 roku, kiedy to został aresztowany i umieszczony w więzieniu w Grodnie. 13 lipca 1943 roku w pobliżu wsi Naumowicze k. Grodna rozstrzelano 50 mieszkańców Lipska i okolic, wśród nich ks. Witolda Kuźmickiego ${ }^{10}$.

Następcą ks. Kuźmickiego w parafii zabłudowskiej był ks. Jerzy Sienkiewicz. Urodził się 15 września 1883 roku w Okińczycach w powiecie Stołpce. Jego rodzice Konstanty i Helena Julia z d. Szeczukowicz należeli do rodziny szlacheckiej. Ukończył gimnazjum klasyczne i wstąpił do seminarium duchownego w Wilnie. 8 czerwca 1908 roku przyjął święcenia kapłańskie i przez ówczesnego administratora apostolskiego diecezji wileńskiej ks. Kazimierza Michalkiewicza został wyznaczony na wikariusza w parafii Ostrobramskiej w Wilnie. W 1914 roku sprawował funkcję wikariusza w katedrze wileńskiej, a od 1916 roku był proboszczem kościoła pod wezwaniem św. Jakuba w Wilnie. W czasie I wojny światowej organizował dożywianie dla głodnych, polskie szkoły dla dzieci oraz pracował w Katolickim Stowarzyszeniu Robotników. Po odzyskaniu przez Polskę niepodległości, w listopadzie 1918 roku, objął opieką duszpasterską organizujące się w Wilnie siły zbrojne. Razem z polskimi oddziałami opuścił Wilno w czasie wojny polsko-bolszewickiej w 1920 roku. W ten sposób został kapelanem wojskowym i brał udział w wojnie jako główny kapelan frontu pod dowództwem generała Stanisława Szeptyckiego ${ }^{11}$. Pod koniec 1920 roku został dziekanem Wojska Polskiego w Toruniu i rektorem kościoła garnizonowego. Przeniesiony w stan spoczynku w 1933 roku, powrócił do pracy duszpasterskiej w archidiecezji wileńskiej. Najpierw został proboszczem w Czarnej Wsi Kościelnej, a od marca

\footnotetext{
${ }^{9}$ Ks. Aleksander Paulin Giedrojć (1871-1942), wikariusz i emeryt parafii pw. św. Apostołów Piotra i Pawła w Zabłudowie w latach 1914-1942. Por. A. GóRsKI, Ks. Aleksander Paulin Giedrojć, „Zabłudów i Okolice” 2014, nr 11, s. 9.

${ }^{10}$ T. KRAHEL, Martyrologia duchowieństwa archidiecezji wileńskiej 1939-1945, Wydawnictwo BUK w Białymstoku, [b.m.w.] i [b.r.w.], s. 235-239.

${ }^{11}$ Stanisław Szeptycki (1867-1950), polski wojskowy, generał major cesarskiej i królewskiej Armii, generał broni Wojska Polskiego, szef Sztabu Generalnego Wojska Polskiego i minister spraw wojskowych II Rzeczypospolitej. Por. M. CzAJKA, M. KAMLER, W. SiENKIEWICZ, Leksykon Historii Polski, s. 736.
} 
1936 roku sprawował funkcję proboszcza w Zabłudowie. W 1939 roku przeniósł się do Warszawy i tam w czasie II wojny światowej uczestniczył w Powstaniu Warszawskim. Po jego upadku był naczelnym kapelanem Armii Krajowej. Po wojnie został proboszczem w parafii Żuków koło Warszawy, gdzie zmarł w 1947 roku ${ }^{12}$.

\section{OGÓLNA CHARAKTERYSTYKA KRONIKI}

Kronika kościoła parafialnego pw. Św. Apostołów Piotra i Pawła w Zabłudowie od momentu powstania była przechowywana wraz z innymi księgami metrykalnymi i dokumentami w Archiwum Parafialnym w Zabłudowie. W 2017 roku najstarsze księgi parafialne, a wśród nich kronika parafialna, zostały przekazane do Archiwum i Muzeum Archidiecezjalnego w Białymstoku. Kronika zapisana jest w brulionie o formacie B4 (250x353 mm), oprawiona w twardą okładkę lekko przetartą na rogach. Zawiera 22 karty obustronnie ponumerowane i przesznurowane trójkolorowym sznurem w białym, czarnym i brązowym kolorze. Sznur jest związany na ostatniej stronie, lecz nie został opieczętowany.

$\mathrm{Na}$ stronie tytułowej znajduje się tytuł i rok rozpoczęcia pisania kroniki. Pozostałe strony od 1 do 41 są zapisane w 3 osobie liczby pojedynczej. Na stronach od 2 do 38 tekst został zapisany jednym charakterem pisma czarnym atramentem. Natomiast na stronach od 38 do 41 pojawia się zapis trzema różnymi charakterami pisma z wykorzystaniem czarnego i niebieskiego koloru atramentu. Na stronie 22, pod datą 25 października i 15 listopada, zostały wklejone dwa fragmenty z prasy katolickiej informujące o „Święcie Akcji Katolickiej w Zabłudowie” i „Święcie Młodzieży w Zabłudowie”. 29 czerwca 1933 roku ks. Witold Kuźmicki obchodził w Zabłudowie 25-lecie święceń kapłańskich, dlatego na stronach 28 i 29 zostały dołączone ulotki: „Jubileusz zasłużonego kapłana” i ulotka Komitetu Obchodu pod tytułem „Dwudziestopięciolecie kapłaństwa księdza Dra Witolda Kuźmickiego w Zabłudowie"13. Trudnością było ustalenie, $\mathrm{z}$ jakich gazet lub czasopism pochodzą wspomniane notatki prasowe, ponieważ zostały z nich wycięte. Na końcu księgi dołączona jest luźna karta formatu A5 z informacją o odbytej uroczystości przystąpienia dzieci do pierwszej Komunii Świętej w dniu 10 sierpnia 1929 roku.

\footnotetext{
${ }^{12}$ A. Szot, Dzieje rzymskokatolickiej parafii pw. św. Apostołów Piotra i Pawła w Zabtudowie, Książnica Podlaska im. Łukasza Górnickiego w Białymstoku i Miejski Ośrodek Kultury w Zabłudowie, Białystok 2003, s. 105-106.

${ }^{13}$ AAB, Kronika kościoła parafialnego w Zabtudowie, rok 1927, s. 28-29.
} 
Prezentowana kronika jest kroniką parafialną, w związku z tym wydarzenia w niej opisane przynajmniej pośrednio odnoszą się do życia parafii, choć nie wszystkie mają charakter stricte religijny. Spośród wydarzeń opisanych w Kronice na szczególną uwagę zasługują: obchody uroczystości patriotycznych oraz opisy pewnych wydarzeń z życia parafii.

\section{UROCZYSTOŚCI PATRIOTYCZNE WEDŁUG KRONIKI}

Ks. Witold Kuźmicki starał się przekazać na łamach omawianej Kroniki najważniejsze wiadomości dotyczące życia parafii, w tym również wydarzeń, które były organizowane przez osoby świeckie. Dotyczyły one nie tylko mieszkańców miasta Zabłudów, lecz także okolicznych miejscowości. Jako gorliwy kapłan i patriota, dużo uwagi poświęcał różnym świętom państwowym, takim jak: Święto Narodowe Trzeciego Maja, obchodzone 3 maja w rocznicę uchwalenia Konstytucji 3 maja. Obchodzenie święta rozpoczęło się w archikatedrze we Lwowie na podstawie dekretu papieża Piusa X z 1909 roku. Upamiętnia ono śluby lwowskie króla Jana Kazimierza, który podczas potopu szwedzkiego powierzył Polskę opiece Matki Bożej. Na wniosek biskupów polskich Święta Kongregacja Obrzędów przeniosła w 1923 roku obchody tego święta na 3 maja. W 1925 roku rozciągnięto je na wszystkie polskie diecezje, tym samym połączono świętowanie rocznicy uchwalenia Konstytucji 3 Maja ze świętem Królowej Korony Polskiej ${ }^{14}$.

W tych uroczystościach, jak zanotował ks. Kuźmicki, które były zorganizowane przez miejscowego duszpasterza i urzędników miasta, w 1927 roku brało udział bardzo dużo osób ${ }^{15}$. Natomiast w 1929 roku autor zaznaczył, że owe uroczystości obchodzono z większą niż w roku ubiegłym okazałością ${ }^{16}$. Świadczy to o lepszym przygotowaniu się do uroczystości oraz większym zaangażowaniu osób świeckich. W kolejnym 1930 roku wspomniał o tym, że „narodowe obchody zaczynają być szablonem bez życia. Miasteczko bez inteligencji, z żydowskim burmistrzem $^{17}$ na nic pomysłowego poza urzędowe polecenie zdobyć się nie potrafi”. Oficjalne uroczystości w 1931 roku, jak zaznaczył autor, polegały na

\footnotetext{
${ }^{14}$ M. STRASZEWICZ, Królowa Polski NMP, w: Encyklopedia Katolicka, t. 9, red. zb., TN KUL, Lublin 2002, kol. 1372-1374.

${ }^{15}$ AAB, Kronika, s. 2.

${ }^{16}$ Tamże, s. 13.

${ }^{17}$ W latach 1928-1932 burmistrzem w gm. Zabłudów był Szewach Gober pochodzenia żydowskiego. Por. Szewach Gober aptekarz, wójt i burmistrz Zabłudowa, „Zabłudów i Okolice” 2019, nr 3 (118), s. 10-11.
} 
pochodzie i przemówieniach dwóch wiecowych krzykaczy, lecz nie pociągnęły za sobą tłumów $^{18}$. Pod datą 3 maja 1933 roku ks. Kuźmicki zapisał, że obchód święta Królowej Korony Polskiej i uroczystości narodowej wypadł okazale, z pewnością dlatego, że w jego przygotowanie włączyły się liczne grupy parafialne $^{19}$. Natomiast w kolejnym, 1934 roku, wobec powstrzymania się urzędów państwowych w mieście od obchodu rocznicy uchwalenia Konstytucji 3 maja, ks. proboszcz urządził obchód w mniejszym zakresie, na który składała się akademia i przemówienie, w którym podkreślił, że „tak modna obecnie rezygnacja ze świąt narodowych, niekorzystnie odbije się na przyszłych pokoleniach"20. W 1935 roku, dzięki zaangażowaniu ks. proboszcza i organizacji Akcji Katolickiej z parafii zabłudowskiej, został urządzony na rynku miejskim obchód Konstytucji 3 maja $^{21}$.

Innym świętem państwowym, a zarazem o wydźwięku kościelnym, jakie dzięki staraniu ks. proboszcza Kuźmickiego było kultywowane w kościele i w mieście Zabłudowie, była rocznica Bitwy Warszawskiej, potocznie zwanej Cudem nad Wista. Stoczona została w dniach od 13 do 15 sierpnia 1920 roku na przedpolach Warszawy, w czasie wojny polsko-bolszewickiej. Ks. Kuźmicki o wydarzeniach związanych z tym świętem informował na łamach kroniki zaledwie kilka razy. 15 sierpnia 1932 roku wspomniał, że Komitet Akcji Katolickiej w rocznicę „Cudu nad Wisłą" urządził w mieście uroczystą akademię ${ }^{22}$. Najprawdopodobniej miało to miejsce w budynku należącym do Straży Ogniowej, ponieważ znajdowało się w nim duże pomieszczenie, które mogło pomieścić znaczną liczbę osób. Dwa lata później, w 1934 roku, ks. Kuźmicki zanotował w jednym zdaniu, że miał miejsce obchód zwycięstwa nad bolszewikami tak zwany „Cud nad Wisłą"23. Trudno jest ustalić czy uroczystości związane z tym wydarzeniem odbyły się w kościele, na rynku w centrum miasta czy też w sali Straży Ogniowej. Natomiast 15 sierpnia 1935 roku, jak zanotował ks. proboszcz, po nabożeństwie parafialnym w miejscowym kościele, Zarząd Akcji Katolickiej urządził akademię z okazji 15-lecia „Cudu nad Wisłą" ${ }^{24}$. Z pewnością miało to miejsce w budynku Straży Ogniowej.

11 listopada 1932 roku w zabłudowskim kościele, jak również w mieście, uroczyście obchodzono 14. rocznicę odzyskania przez Polskę niepodległości.

\footnotetext{
${ }^{18}$ AAB, Kronika, s. 19.

${ }^{19}$ Tamże, s. 27.

${ }^{20}$ Tamże, s. 32.

${ }^{21}$ Tamże, s. 36.

${ }^{22}$ Tamże, s. 25.

${ }^{23}$ Tamże, s. 33.

${ }^{24}$ Tamże, s. 37-38.
} 
W związku z tym wydarzeniem ks. Witold Kuźmicki zanotował w kronice, że w mieście, wobec władz: starościńskiej i „Strzelca” odbyła się uroczystość niepodległościowa. Po nabożeństwie organizacje ustawiły się w czworobok na Rynku, zaś raport przyjął Starosta Białostocki Jan Mieszkowski. Następnie pochód ruszył na cmentarz św. Krzyża, gdzie na grobie żołnierzy złożono wieńce. Przemawiali: Komendant okręgowy związku strzeleckiego, Starosta i przedstawiciel młodzieży. Natomiast dzieci deklamowały wiersze związane z tą uroczystością. Na zakończenie odbyła się defilada, która miała miejsce na szosie prowadzącej od strony cmentarza do miasta ${ }^{25}$.

\section{4. ŻYCIE PARAFII WEDEUG KRONIKI}

W ciągu dwunastu lat, od 1927 do 1938 roku, w jakich powstawała kronika parafialna, ówczesny Arcybiskup Wileński Romuald Jałbrzykowski czterokrotnie odwiedził ziemię zabłudowską. Trzy razy podczas wizytacji pasterskich parafii. Po raz pierwszy 4 maja 1928 roku, oprócz zwizytowania parafii, spotkał się na konferencji z duchowieństwem z całego dekanatu ${ }^{26}$. Kolejny raz ks. Arcybiskup przebywał $\mathrm{w}$ Zabłudowie $\mathrm{w}$ dniach od 27 do 28 maja 1931 roku $^{27}$. Wówczas, w trakcie wizytacji pasterskiej, udzielił sakramentu bierzmowania 222 osobom $^{28}$. Po raz trzeci ks. Jałbrzykowski przyjechał na wizytację do parafii zabłudowskiej 17 sierpnia 1937 roku $^{29} \mathrm{i}$ było to połączone $\mathrm{z}$ poświęceniem nowo wybudowanego domu katechetycznego pod nazwą „Ognisko parafialne im. św. Anny”30. 17 października 1931 roku, w czasie podróży na konsekrację kościoła w Tryczówce Arcybiskup Romuald Jałbrzykowski, przejeżdżając przez Zabłudów, został powitany przez Stowarzyszenie Młodzieży Polskiej oraz dzieci szkolne ${ }^{31}$.

16 listopada 1930 roku w Polsce odbyły się przedterminowe wybory do Sejmu, spowodowane rozwiązaniem parlamentu II kadencji przez Prezydenta Rzeczypospolitej Ignacego Mościckiego ${ }^{32}$. Decyzja o przyspieszonych wyborach

${ }^{25}$ Tamże, s. 26.

${ }^{26}$ Tamże, s. 10.

${ }^{27}$ Tamże, s. 20.

${ }^{28}$ AAB, Księga Pobierzmowanych Kościoła parafialnego w Zabłudowie Dekanatu Białostockiego Archidiecezji Wileńskiej, k. 29v-38v.

${ }^{29}$ AAB, Kronika, s. 40.

${ }^{30}$ Szerzej na ten temat zob.: Kronika, ,Jutrzenka Białostocka” 1937, nr 9, s. 14.

${ }^{31}$ AAB, Kronika, s. 21.

${ }^{32}$ Ignacy Mościcki (1867-1946), polski chemik, polityk, w latach 1926-1939 prezydent Rzeczypospolitej Polskiej. Naukowiec, wynalazca, budowniczy polskiego przemysłu chemicznego. W 1939 
została podjęta na wniosek Józefa Piłsudskiego ${ }^{33}$. Ówczesne koła rządowe obawiały się niemożności zmiany konstytucji w pożądanym przez nie kierunku, czyli ograniczenia władzy ustawodawczej na rzecz znacznego wzmocnienia władzy wykonawczej.

W związku z tym kilka dni przed wyborami 14 listopada 1930 roku, jak zapisał ks. Witold Kuźmicki w kronice parafialnej, dla celów wyborczych zjednywano ludność przez otwarcie i poświęcenie w Zabłudowie Ośrodka Zdrowia, przytułku dla starców i miejscowego magistratu, w którym przemawiał wówczas wojewoda, zalecając popieranie rządu ${ }^{34} .16$ listopada odbyło się głosowanie do Sejmu. Ludność w swej większości należąca do Piasta, jak zaznaczył autor Kroniki, i posiadająca na zblokowanej lewicy swoich kandydatów, głosowała na listę $\mathrm{nr}$ 7. Jednakże więcej niż tysiąc głosów oddano na kandydatów z listy $\mathrm{nr} 19^{35}$.

Po wyborach do Sejmu, 23 listopada 1930 roku odbyły się wybory do Senatu. W gminie zabłudowskiej, jak zaznaczył autor Kroniki, w tym dniu wyborcy niechętnie szli do urn wyborczych, wobec nadużyć, jakich dopuszczała się ,jedynka” podczas wcześniejszych wyborów do Sejmu ${ }^{36}$.

Ks. Witold Kuźmicki wielokrotnie na kartach kroniki wspominał o różnych wydarzeniach, jakie miały miejsce w Zabłudowie lub też w okolicznych miejscowościach, a w których brał udział. 25 kwietnia 1928 roku staraniem mieszkańców wsi: Kamionka, Zajezierce i Zacisze, oraz dzięki znacznym ofiarom pana Mikołaja Kawelina $^{37}$ z Majówki, księcia Jerzego Lubomirskiego ${ }^{38}$ z Dojlid oraz Centralnego Towarzystwa Rolniczego w Białymstoku, rozpoczęto budowę Domu Ludowego w Kamionce $^{39}$. Dziekan białostocki, ks. Aleksander Chodyko ${ }^{40}$ jako

roku internowany w Rumunii, następnie wyjechał do Szwajcarii. Por. M. CZAJKA, M. KAMLER, W. SIENKIEWICZ, Leksykon Historii Polski, s. 494-495.

${ }^{33}$ Józef Piłsudski (1867-1935), polski działacz społeczny i niepodległościowy, żołnierz, polityk, mąż stanu, twórca Polskiej Organizacji Wojskowej, kierownik Komisji Wojskowej i Tymczasowej Rady Stanu. Od 11 listopada 1918 roku naczelny wódz Armii Polskiej, w latach 1918-1922 naczelnik państwa, pierwszy marszałek Polski, dwukrotny premier Polski w latach 1926-1928 i 1930 roku. Por. M. CZajKa, M. Kamler, W. SienKiewicz, Leksykon Historii Polski, s. 566.

${ }^{34}$ AAB, Kronika, s. 16.

${ }^{35}$ Tamże, s. 17.

${ }^{36}$ Tamże, s. 17.

${ }^{37}$ Mikołaj Kawelin (1865-1944), carski pułkownik, prezes klubu piłkarskiego Jagiellonia Białystok w latach 1932-1935, właściciel majątku Majówka w gminie Supraśl. Por. A. OsTAPOwicz, Dzieje wsi Rafatówka, Zabłudów 2015, s. 21-22.

${ }^{38}$ Jerzy Książę Rafał Alfred Lubomirski herbu Szreniawa bez Krzyża (1887-1978), polski szlachcic, właściciel dóbr Dojlidy. Por. W. RoszKOWSKI, Lista największych właścicieli ziemskich w Polsce w 1922 roku, „Przegląd Historyczny” [Wydawnictwo DiG],74 (983), nr 2, s. 284.

${ }^{39}$ Szerzej na ten temat zob.: Budowa Domu Ludowego we wsi Kamionce, gmina Zabłudów, „Dziennik Białostocki” 1928, nr 25, s. 4. 
jeden z wielu zaproszonych gości, poświęcił kamień węgielny pod budowę tego domu $^{41}$. 9 lipca 1932 roku ks. Kuźmicki dokonał poświęcenia kamienia węgielnego pod budynek szkoły we wsi Krynickie. W przemówieniu podkreślił hart ducha, jaki panował i panuje wśród mieszkańców wioski, którzy potrafili w czasie największego ucisku rusyfikacyjnego odrzucić propozycję rosyjskiego rządu zaborczego, który chciał tam założyć rosyjskie seminarium nauczycielskie ${ }^{42}$. Po tych uroczystościach, tego samego dnia, został poświęcony budynek mleczarni spółdzielczej w Zabłudowie ${ }^{43}$.

Smutne wydarzenia związane ze śmiercią znanych osób, na kartach kroniki, pojawiają się sporadycznie. 17 maja 1935 roku, tydzień po śmierci pierwszego marszałka Polski Józefa Piłsudskiego, w kościele zabłudowskim zostało odprawione nabożeństwo żałobne. Po modlitwach w kościele odbyła się okolicznościowa akademia na rynku, na którą przybyły dzieci szkolne, sołtysi z okolicznych miejscowości i miejscowi urzędnicy ${ }^{44}$. Natomiast 9 stycznia 1936 roku, jak zanotował autor kroniki, w kościele zabłudowskim odbył się pogrzeb Jana Kalinowskiego ${ }^{45}$, zabitego przez kolegę $w$ świetlicy strzeleckiej. Śmierć strzelca w tych warunkach zrobiła ogromne wrażenie w całym mieście i okolicznych miejscowościach ${ }^{46}$.

Kronika kościoła parafialnego w Zabłudowie, napisana przez ks. Witolda Kuźmickiego i ks. Jerzego Sienkiewicza, jest dziełem obiektywnym. Autorzy nie stronią od krytycznych uwag o przedstawianych osobach i faktach, ani nie wynoszą swoich zasług ponad pracę innych osób. W przeszłości Kronika parafii Zabłudów dostarczyła cennych materiałów źródłowych do pracy napisanej przez ks. Adama Szota pod tytułem „Dzieje Rzymskokatolickiej parafii p.w. św. Apostołów Piotra i Pawła w Zabłudowie". Należy jednak stwierdzić, że omawiane

\footnotetext{
${ }^{40}$ Ks. Aleksander Chodyko (1880-1946), proboszcz parafii pw. Wniebowzięcia NMP w Białymstoku, dziekan białostocki i wikariusz generalny na dekanat białostocki w latach 1920-1946; por. T. KRAHEL, Martyrologia duchowieństwa, s. 100-104.

${ }^{41}$ AAB, Kronika, s. 10.

${ }^{42}$ Szerzej na ten temat zob.: Wieś w dążeniu do oświaty, „Dziennik Białostocki” 1932, nr 193, s. 4.

${ }^{43}$ AAB, Kronika, s. 25.

${ }^{44}$ Tamże, s. 36-37.

${ }^{45}$ Jan Kalinowski (1920-1936), 04.01.1936 roku, podczas bójki z kolegą Józefem Laskowskim w świetlicy strzeleckiej w Zabłudowie został ranny w głowę i następnego dnia zmarł w szpitalu św. Rocha w Białymstoku. Zob. W sprzeczce zabit kolegę, ,Dziennik Białostocki” 1936, nr 85, s. 6.

${ }^{46}$ AAB, Kronika, s. 38.
} 
dzieło stanowi ważne i jeszcze nie w pełni wykorzystane źródło do dalszych badań historycznych nie tylko parafii zabłudowskiej, lecz również nad dziejami miasta i gminy Zabłudów.

\section{BIBLIOGRAFIA}

\section{1. ŹRÓDŁA ARCHIWALNE}

Archiwum Archidiecezjalne w Białymstoku (AAB)

Inwentarz Zabtudowskiego Rzymsko-katolickiego kościoła z 1927 roku (bez sygnatury)

Kronika kościoła parafialnego w Zabtudowie, rok 1927 (bez sygnatury)

Kronika Pobierzmowanych Kościoła parafialnego w Zabtudowie Dekanatu Białostockiego Archidiecezji Wileńskiej (bez syg.)

\section{OPRACOWANIA I ARTYKUŁY}

Budowa Domu Ludowego we wsi Kamionce, gmina Zabtudów, „Dziennik Białostocki” 1928, nr 25.

Czajka M., Kamler M., Sienkiewicz W., Leksykon Historii Polski, Wydawnictwo Wiedza Powszechna, Warszawa 1995.

GóRSKi A., Ks. Aleksander Paulin Giedrojć, „Zabłudów i Okolice” 2014, nr 11.

HоєоDOK S., Jałbrzykowski Romuald abp, w: Encyklopedia Katolicka, t. 7, red. zb., TN KUL, Lublin 1997, kol. 737-738.

KRAHEL T., Martyrologia duchowieństwa archidiecezji wileńskiej 1939-1945, Wydawnictwo BUK w Białymstoku, [b.m.w.] i [b.r.w].

Kronika, w: Stownik literatury staropolskiej, red. T. Michałowska, Zakład Narodowy im. Ossolińskich, Wrocław 1998.

Kronika, ,Jutrzenka Białostocka” 1937, nr 9.

KUFEL R.R., Jak prowadzić kronikę parafialna, Agencja Wydawnicza „PDN”, Zielona Góra 2014.

Maroszek J., Prawa i przywileje miasta i dóbr ziemskich Zabłudów, Dział Wydawnictw Filii UW, Białystok 1994.

N.A., Kronika parafialna, „Wiadomości Archidiecezjalne Wileńskie” 1927, nr 15.

Ostapowicz A., Dzieje wsi Rafałówka, Zabłudów 2015.

Roszkowski W., Lista największych właścicieli ziemskich w Polsce w 1922 roku, „Przegląd Historyczny" [Wydawnictwo DiG], 74(1983), nr 2, s. 281-289.

Straszewicz M., Królowa Polski NMP, w: Encyklopedia Katolicka, t. 9, red. A. Szostek, TN KUL, Lublin 2002, kol. 1372-1374.

Szewach Gober aptekarz, wójt i burmistrz Zabłudowa, „Zabłudów i Okolice” 2019, nr 3 (118).

Szot A., Dzieje rzymskokatolickiej parafii pw. św. Apostołów Piotra i Pawła w Zabłudowie, Książnica Podlaska im. Łukasza Górnickiego w Białymstoku i Miejski Ośrodek Kultury w Zabłudowie, Białystok 2003.

Szot A., Zabłudów, w: Encyklopedia Katolicka, t. 20, red. E. Gigilewicz i in., TN KUL, Lublin 2014, kol. 1139-1140

W sprzeczce zabit kolege, „Dziennik Białostocki” 1936, nr 85.

Wieś w dążeniu do oświaty, „Dziennik Białostocki” 1932, nr 193. 


\section{KRONIKA KOŚCIOŁA PARAFIALNEGO \\ PW. ŚW. APOSTOŁÓW PIOTRA I PAWŁA W ZABŁUDOWIE \\ JAKO ŹRÓDŁO DO BADAŃ NAD DZIEJAMI MIASTA}

\section{Streszczenie}

Celem artykułu jest omówienie problematyki dotyczącej wydarzeń, jakie miały miejsce w mieście Zabłudów w latach 1927-1938. W szczególności analizie poddana została kronika kościoła parafialnego pod wezwaniem św. Ap. Piotra i Pawła w Zabłudowie napisana przez ówczesnych proboszczów ks. Witolda Kuźmickiego i ks. Jerzego Sienkiewicza. Autorzy w omawianej kronice skupili się nie tylko na sprawach stricte religijnych, lecz także na opisaniu wydarzeń dotyczących wielu uroczystości patriotycznych obchodzonych w omawianym okresie przez mieszkańców miasta i okolicznych miejscowości. W artykule podjęto również próbę przypomnienia wartości dokumentu w postaci kroniki jako ważnego historycznego źródła informacji. Artykuł przeznaczony jest nie tylko dla historyków, ale także dla wszystkich zainteresowanych historią regionalną z okresu międzywojennego.

Słowa kluczowe: kronika; Zabłudów; parafia w Zabłudowie; okres międzywojenny. 